Article

\title{
Authigenic and Detrital Minerals in Peat Environment of Vasyugan Swamp, Western Siberia ${ }^{\dagger}$
}

\author{
Maxim Rudmin*(D), Aleksey Ruban, Oleg Savichev $\mathbb{B}^{\circ}$, Aleksey Mazurov, Aigerim Dauletova \\ and Olesya Savinova \\ Division for Geology, Tomsk Polytechnic University, 634050 Tomsk, Russia; ruban@tpu.ru (A.R.); \\ osavichev@mail.ru (O.S.); akm@tpu.ru (A.M.); ikerimdb@gmail.com (A.D.); logvinenkoov@tpu.ru (O.S.) \\ * Correspondence: rudminma@tpu.ru; Tel.: +78-3822-60-62-45 \\ + The paper is an extended version of our paper published in 1st International Electronic Conference on Mineral \\ Science, 16-31 July 2018.
}

Received: 24 September 2018; Accepted: 31 October 2018; Published: 1 November 2018

check for updates

\begin{abstract}
Studies of mineral-forming processes in modern peat bogs can shed light on metal concentrations and their cycling in similar environments, especially in geological paleoanalogs. In terms of the mineralogical and geochemical evolution of peat bog environments, the Vasyugan Swamp in Western Siberia is a unique scientific object. Twelve peat samples were collected from the Vasyugan Swamp up to the depth of $275 \mathrm{~cm}$ at $25 \mathrm{~cm}$ intervals. The studied peat deposit section is represented by oligotrophic $(0-100 \mathrm{~cm})$, mesotrophic $(100-175 \mathrm{~cm})$, and eutrophic $(175-275 \mathrm{~cm})$ peat, and this is underlain by basal sediments (from $275 \mathrm{~cm}$ ). About 30 minerals were detected using scanning electron microscopy (SEM), X-ray diffraction (XRD), and Raman spectroscopy. The observed minerals are divided into detrital, clay, and authigenic phases. The detrital minerals found included quartz, feldspar, ilmenite, rutile, magnetite, zircon, and monazite. When passing from basal to oligotrophic bog sediments, the clay minerals changed from illite-smectite to kaolinite. Authigenic minerals are represented by carbonates (calcite and dolomite), iron (hydro-)oxides, galena, sphalerite, pyrite, chalcopyrite, $\mathrm{Zn}-\mathrm{Pb}-\mathrm{S}$ mineral, barite, baritocelestine, celestine, tetrahedrite, cassiterite, REE phosphate, etc. The regular distribution of mineral inclusions in peat is associated with the (bio)geochemical evolution of the environment. The formation of authigenic $\mathrm{Zn}, \mathrm{Pb}$ and $\mathrm{Sb}$ sulfides is mainly confined to anaerobic conditions that exist in the eutrophic peat and basal sediments. The maximum amount of pyrite is associated with the interval of $225-250 \mathrm{~cm}$, which is the zone of transition from basal sediments to eutrophic peat. The formation of carbonate minerals and the decreasing concentration of clay in the association with local sulfide formation (galena, sphalerite, chalcopyrite, stibnite) begins above this interval. The peak of specific carbonation appears in the $125-150 \mathrm{~cm}$ interval of the mesotrophic peat, which is characterized by $\mathrm{pH} 4.9-4.5$ of pore water. Kaolinite is the dominant clay mineral in the oligotrophic peat. Gypsum, galena, chalcopyrite, sphalerite, and relicts of carbonate are noted in association with kaolinite. Changes in oxygen concentrations are reflected in newly formed mineral associations in corresponding intervals of the peat. This can be explained by the activity of microbiological processes such as the anaerobic oxidation of methane (AOM) and bacterial sulfate reduction (BSR), expressed in specific carbonatization $(100-225 \mathrm{~cm})$ and sulfidization $(175-250 \mathrm{~cm})$, respectively.
\end{abstract}

Keywords: mineral formation; peat bog; Vasyugan Swamp; Western Siberia

\section{Introduction}

The Vasyugan Swamp (or the Vasyugan Mire) is the largest swamp on the planet with a total area of more than 5,250,000 hectares [1], and has accumulated a huge amount of carbon (5.1 billion 
t) and peat in Western Siberia [1,2]. The huge peat deposits (around 18.7 billion $t$ [1]) within the Vasyugan Swamp are important scientific objects. Peat is an organic sediment, which the color of which varies from light brown almost to black, and is formed under waterlogged conditions from the partial decomposition of mosses and other bryophytes, sedges, grasses, shrubs, or trees [3]. However, peat is not only a specific organic deposit but also a unique repository for metals and their compounds [3-10], accompanied by the mobilization and concentration of elements $[6,7,11,12]$ under the conditions of swamp evolution. Various biogeochemical processes in peat bogs lead to the formation of new mineral phases such as sulfides (pyrite, marcasite, sphalerite, galena), carbonates (calcite, siderite), sulfates (gypsum, anhydrite, jarosite), iron oxides (goethite), aragonite, calcite, opal-A, halite, etc. $[3,7,9,10,13-16]$.

To date, there are several issues regarding the metal sources [3,6,7], the conditions of mineral formation [8,14,17-19], and the subsequent evolution of minerals [10] in peat deposits. Metal enrichment of peat is interpreted by one of the following processes or their combination: interaction with underlying rocks and diffusion from groundwater $[4,6,7,10,13]$, precipitation of atmospheric dust caused by natural or anthropogenic factors [9,15,20-23], release from plants $[4,7,24]$, and detrital input from surrounding rocks $[4,6,10,12]$. Peat comprises relatively young Cenozoic organic deposits that can be studied considering many parameters of the geological environment, such as the composition of waters and atmospheric dust, $\mathrm{pH}$ and Eh conditions, growth rates, botanical composition, microbiological processes, etc. Studies of mineral formation processes and metal sources are the key points in constructing the concept of peat environment evolution, with the formation of their metallogenic appearance as the initial substrate (or "protholite") for carbonaceous sedimentary rocks (lignite, coal, etc.).

In this regard, the Vasyugan peat bog is unique. The studied area (N56 $\left.55^{\prime} 30^{\prime \prime}, \mathrm{E} 82^{\circ} 42^{\prime} 36^{\prime \prime}\right)$ is a pine-shrub-sphagnum bog (Figure 1c) [1] located in the southeastern corner of the Vasyugan Swamp (Figure 1a) between the rivers Iksa and Bakchar (the drainage system: the rivers Iksa and Bakchar to the river Chaya to the river $\mathrm{Ob}$ to the Kara Sea). The peat deposit (or peat layer, peat sediments, peat sequence) has a thickness between 1.75 and $3.8 \mathrm{~m}$. The studied sequence (Figure 1b) consists of oligotrophic peat (from the surface to $1 \mathrm{~m}$ down), mesotrophic peat (from approximately 1.0 to $1.8 \mathrm{~m}$ down), eutrophic peat (from 1.8 to $2.25 \mathrm{~m}$ down), organic-rich sediments (from 2.25 to $2.75 \mathrm{~m}$ down), and basal sediments (from $2.75 \mathrm{~m}$ ) on the basis of botanical composition [8] and ash content. The peat type reflects the nature of the water and mineral nutrition of bog vegetation, the remnants of which form peat.

(a)

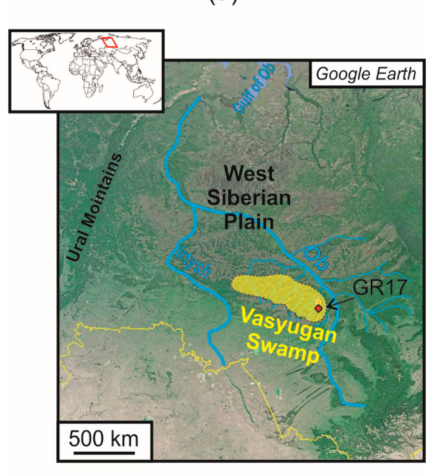

(b)

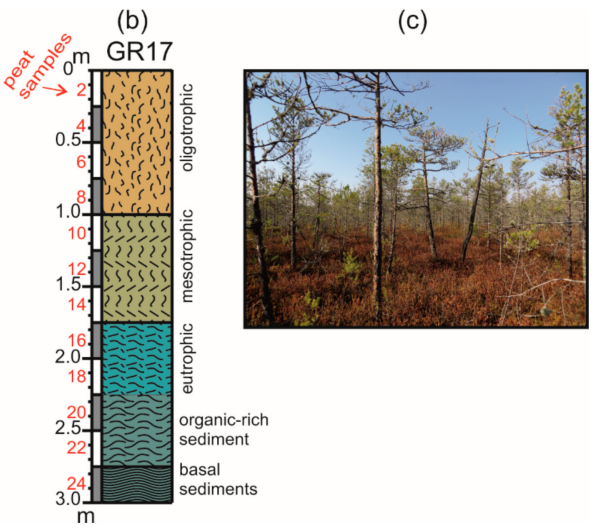

Figure 1. Map of the studied peat bog location (a) stratigraphy of the studied core (b) and photo of the studied pine-shrub-sphagnum bog (c) Oligotrophic peat (0-1 m) consists of Sphagnum fuscum, mesotrophic peat (up to 1.75-1.8 m) depth is comprised of Sphagnum magellanicum peat, eutrophic peat (1.8-2.25 m) and organic-rich sediment (2.25-2.75 m) consist of Sphagnum jensenii and woody peat, and the basal sediments (from 2.75) are presented by loam. 
Higher trace element concentrations in peat were previously described in the studied region $[8,25,26]$, and some mineral phases such as monazite, xenotime, crandallite group, and zircon [23] were found with the interpretation of their source as atmospheric dust. The aim of this work was to study the conditions for the formation and distribution of authigenic mineral forms in a peat deposit to evaluate possible metal sources and mechanisms of their mobilization and concentration.

\section{Materials and Methods}

The detailed mineralogical investigations were carried out by using samples of peat and basal sediments (12 samples) which were collected from a drill hole (N56 $\left.55^{\prime} 30^{\prime \prime}, \mathrm{E} 82^{\circ} 42^{\prime} 36^{\prime \prime}\right)$ using a Russian peat corer (diameter $7.5 \mathrm{~cm}$ ) at $25 \mathrm{~cm}$ intervals.

The ash content was determined by drying ash peat samples at $450{ }^{\circ} \mathrm{C}$ for $10 \mathrm{~h}$ and expressing results as a percentage of the dry weight of the sample at $60^{\circ} \mathrm{C}$. Ash is important in the characterization of peat type.

Previously, dried peat samples were preliminarily crushed and soaked for $1 \mathrm{~h}$ in water to separate the inorganic phase without heat treatment. Furthermore, the samples were poured into a 500-mesh sieve and placed in a water-filled ultrasonic bath (Retsch UR 1) for $90 \mathrm{~min}$ so that the upper edge of the sieve was above the water level. The liquid drained from the ultrasonic bath was settled for $24 \mathrm{~h}$, after which the inorganic fraction precipitated at the bottom. Complete drying of the obtained fraction was carried out in an oven at $60^{\circ} \mathrm{C}$ for $180 \mathrm{~min}$. Specimens were cleaned in an air stream to remove loose mineral grains.

The $\mathrm{pH}$ of pore water from each peat sample was measured using a laboratory $\mathrm{pH}$ meter in naturally wet samples.

The mineralogical characterization of the thin layer $\left(1 \mathrm{~cm}^{2}\right)$ of peat sample, ash, and inorganic fraction was carried out using a combination of X-ray diffraction (XRD) and scanning electron microscopy (SEM) coupled with an energy-dispersive spectrometer (SEM-EDS). The bulk mineralogical composition of the whole rock, inorganic fractions and separately clay-sizes fraction (for organic-rich sediments and loam) was determined by using a Rigaku Ultima IV X-ray diffractometer at the Tomsk Oil and Gas Research and Design Institute, with $\mathrm{Cu}-\mathrm{K} \alpha$ radiation at a current of $30 \mathrm{~mA}$ and a voltage of $40 \mathrm{kV}$. Samples for XRD analysis were obtained by gentle grinding of the whole rock (loam) and inorganic fraction (peat) to a fine powder up to amean grain size of about $10 \mu \mathrm{m}$. Less than $10 \mu \mathrm{m}$ size-fractions of powdered samples were scanned from $3-70^{\circ} 2 \theta$, with a step of $0.02^{\circ}$ at a scanning rate of $1 \mathrm{~s}$ and a divergence slit (DS) of $1.2 \mathrm{~mm}$. Clay samples (less than $2 \mu \mathrm{m}$ ) were obtained by disaggregation and ultrasonic dispersion so as to prepare an aqueous suspension, followed by sedimentation over 8 or $16 \mathrm{~h}$. Each sample was scanned initially after air drying (i.e., untreated), subsequently by ethylene-glycol solvation by vaporization in a desiccator for $24 \mathrm{~h}$, and after heat treatment at $350^{\circ} \mathrm{C}$ for $1 \mathrm{~h}$. Comprehensive identification of clay minerals was carried out in terms of the following procedures provided in [27] and [28]. Quantitative mineralogical analyses of the whole rock data were performed by a Rietveld analysis [29] using PDXL and Siroquant software [30]. A thin layer of each sample (ash and/or inorganic fraction) was fixed to a double-sided $9 \mathrm{~mm}$ carbon tab placed on an aluminum stub and was carbon coated $(15 \mu \mathrm{m})$ prior to the analysis. These prepared samples were studied under a TESCAN VEGA 3 SBU scanning electron microscope (SEM) and an OXFORD X-Max 50 energy-dispersive adapter (EDS) with a $20 \mathrm{kV}$ accelerating voltage, specimen current of $12 \mathrm{nA}$, and a spot diameter of approximately $2 \mu \mathrm{m}$. A confocal Thermo Fisher Scientific DXR2 Raman spectrometer was used to identify the mineral phases. All measurements were carried out with a laser wavelength of $532 \mathrm{~nm}$ and $20-25 \mathrm{~mW}$ power. Spectra were usually acquired over a $30 \mathrm{~s}$ period for $0-3.300 \mathrm{~cm}^{-1}$ with a three-rate accumulation. 


\section{Results}

\subsection{Bulk Mineral Composition of Peat Inorganic Fraction}

The ash content in peat (Figure 2) ranges between $1.1 \%$ and $5.1 \%$. The ash content increases up to $22.6 \%$ from a depth of $2.25 \mathrm{~m}$ and had the maximum amount of $87.6 \%$ and $95.3 \%$ in organic-rich sediment (depth 2.5-2.75 m) and basal (depth 2.75-3 m) sediment, respectively. The oligotrophic peat sequence was characterized by decreasing ash content from $2.8 \%$ to $1.1 \%$ with increasing depth to $1 \mathrm{~m}$. Furthermore, the ash content increased from $2.5 \%$ to $5.1 \%$ in mesotrophic and eutrophic peat sequences. The zone of transition from basal sediments to peat was fixed in the depth interval of 2.25-2.75 m (so-called organic-rich sediment), which was reflected in a contrasting increase of ash content to $22.6-87.6 \%$ and a decrease of moisture from $77.4 \%$ to $4.7 \%$. A strong inverse correlation $\left(r^{2}=0.97\right)$ between the moisture and the ash content was found. The pore water $\mathrm{pH}$ of peat had a range from 4.6 to 6.0. In contrast, the bottom sediments had a high $\mathrm{pH}$ of 8.1 .

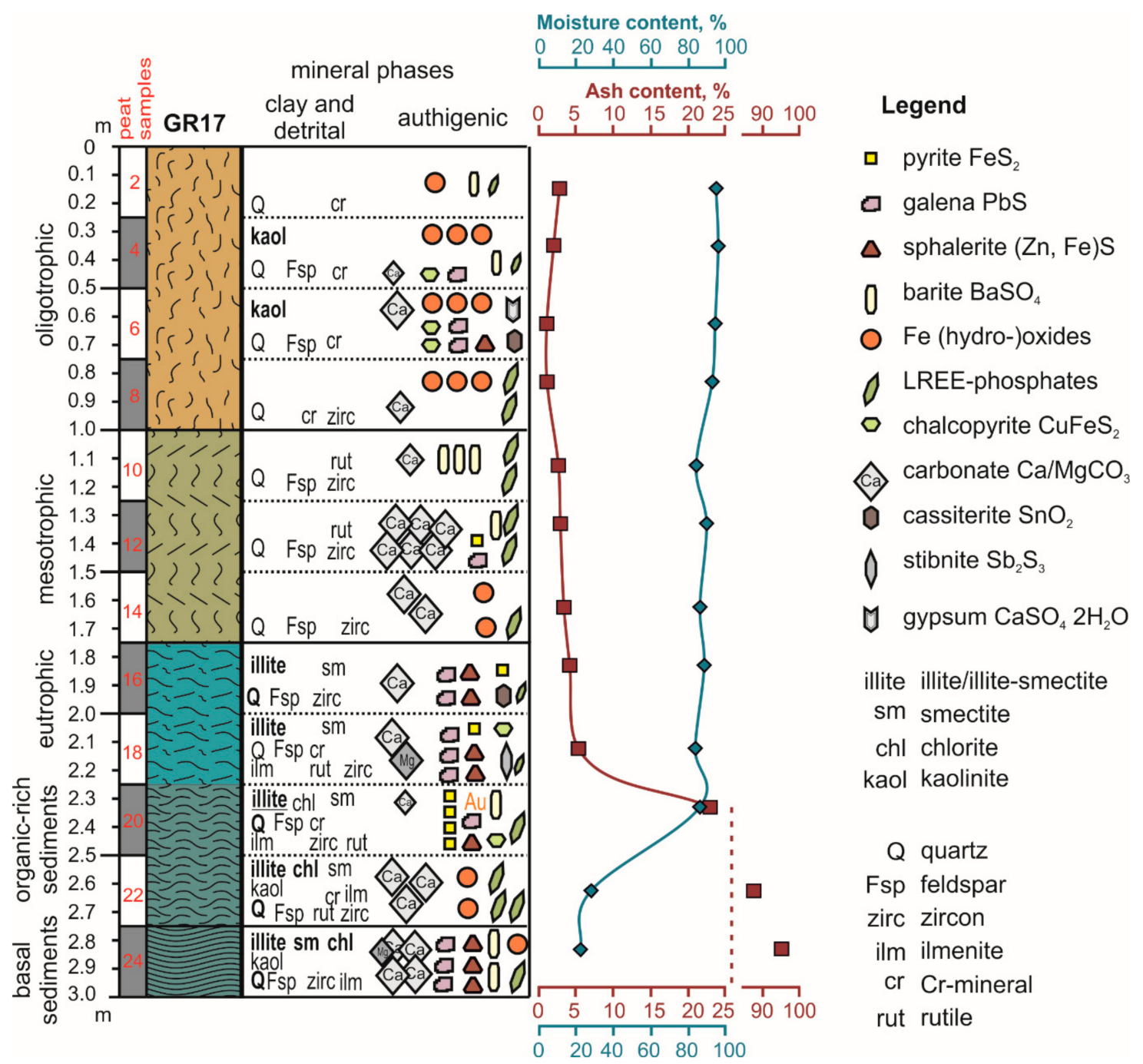

Figure 2. Bulk mineral composition in inorganic fraction, ash, and moisture content (\%) of peat and basal sediments. Oligotrophic peat (0-1 m) consists of Sphagnum fuscum, mesotrophic peat (up to $1.75-1.8 \mathrm{~m}$ ) depth is comprised of Sphagnum magellanicum peat, eutrophic peat $(1.8-2.25 \mathrm{~m})$ and organic-rich sediment $(2.25-2.75 \mathrm{~m})$ consist of Sphagnum jensenii and woody peat, and the basal sediments (from 2.75 ) are presented by loam. 
More than 30 minerals (Table 1) were found in inorganic fractions of peat and basal loam using a complex of analytical methods (SEM, XRD, Raman spectroscopy). Mineral composition was divided into three groups based on morphological and textural characteristics: detrital, authigenic, and clay. Partially resorbed, erosional, and dissolution surfaces grains of minerals indicate detrital origin. The absence of such characteristics and spheroidal or crystalline grain shapes reflects in situ (authigenic) formation of minerals. The detrital minerals are quartz, feldspars, ilmenite, rutile, magnetite, zircon, monazite, chromite, and amphiboles. Clay minerals are represented by illite, kaolinite, smectite, and chlorite. Authigenic minerals are the following: carbonates (calcite and dolomite), ferruginous (hydro-)oxides (ferrihydrite and goethite), galena, sphalerite, pyrite, chalcopyrite, barite, celestine, stibnite, cristobalite, halite, phosphate of light rare earth elements (LREE phosphate or rhabdophane), gypsum, baritocelestine, cassiterite, etc.

Table 1. Mineralogy of selected samples from Vasygan Swamp, Western Siberia.

\begin{tabular}{|c|c|c|c|c|}
\hline Sample & Detrital Minerals & Clay Minerals & Authigenic Minerals & Identified by \\
\hline 2 & quartz, chromite & & Fe-(hydro-)oxides, barite, rhabdophane & SEM-EDS \\
\hline 4 & $\begin{array}{l}\text { quartz, feldspars, } \\
\text { chromite }\end{array}$ & kaolinite & $\begin{array}{l}\text { Fe-(hydro-)oxides, rhabdophane, } \\
\text { chalcopyrite, galena, barite, calcite }\end{array}$ & XRD, SEM-EDS \\
\hline 6 & $\begin{array}{l}\text { quartz, feldspars, } \\
\text { chromite }\end{array}$ & kaolinite & $\begin{array}{l}\text { Fe-(hydro-)oxides, chalcopyrite, galena, } \\
\text { sphalerite, cassiterite, gypsum, calcite }\end{array}$ & XRD, SEM-EDS \\
\hline 8 & $\begin{array}{l}\text { quartz, zircon, } \\
\text { chromite }\end{array}$ & & Fe-(hydro-)oxides, rhabdophane, calcite & SEM-EDS \\
\hline 10 & $\begin{array}{l}\text { quartz, feldspars, } \\
\text { rutile, zircon }\end{array}$ & & barite, rhabdophane, calcite & SEM-EDS \\
\hline 12 & $\begin{array}{l}\text { quartz, feldspars, } \\
\text { rutile, zircon }\end{array}$ & & $\begin{array}{l}\text { calcite, rhabdophane, barite, pyrite, } \\
\text { galena, }\end{array}$ & $\begin{array}{l}\text { XRD, SEM-EDS, } \\
\text { Raman }\end{array}$ \\
\hline 14 & $\begin{array}{l}\text { quartz, feldspars, } \\
\text { zircon }\end{array}$ & & $\begin{array}{l}\text { calcite, Fe-(hydro-)-oxides, } \\
\text { rhabdophane }\end{array}$ & $\begin{array}{l}\text { SEM-EDS, } \\
\text { Raman }\end{array}$ \\
\hline 16 & $\begin{array}{l}\text { quartz, feldspars, } \\
\text { zircon }\end{array}$ & illite, smectite & $\begin{array}{l}\text { galena, sphalerite, pyrite, cassiterite, } \\
\text { rhabdophane, calcite }\end{array}$ & XRD, SEM-EDS \\
\hline 18 & $\begin{array}{l}\text { quartz, feldspars, } \\
\text { chromite, ilmenite, } \\
\text { rutile, zircon }\end{array}$ & illite, smectite & $\begin{array}{l}\text { galena, sphalerite, pyrite, chalcopyrite, } \\
\text { rhabdophane, stibnite, calcite, dolomite }\end{array}$ & XRD, SEM-EDS \\
\hline 20 & $\begin{array}{l}\text { quartz, feldspars, } \\
\text { chromite, ilmenite, } \\
\text { rutile, zircon }\end{array}$ & $\begin{array}{l}\text { illite, smectite, } \\
\text { chlorite }\end{array}$ & $\begin{array}{c}\text { pyrite, barite, galena, sphalerite, } \\
\text { chalcopyrite, rhabdophane, gold, calcite }\end{array}$ & XRD, SEM-EDS \\
\hline 22 & $\begin{array}{l}\text { quartz, feldspars, } \\
\text { chromite, ilmenite, } \\
\text { rutile, zircon }\end{array}$ & $\begin{array}{l}\text { illite, smectite, } \\
\text { chlorite }\end{array}$ & calcite, Fe-(hydro-)oxides, rhabdophane & $\begin{array}{l}\text { XRD, SEM-EDS, } \\
\text { Raman }\end{array}$ \\
\hline 24 & $\begin{array}{l}\text { quartz, feldspars, } \\
\text { ilmenite, zircon }\end{array}$ & $\begin{array}{l}\text { illite, smectite, } \\
\text { chlorite }\end{array}$ & $\begin{array}{c}\text { calcite, galena, sphalerite, barite, } \\
\text { dolomite, Fe-(hydro-)oxides, } \\
\text { rhabdophane }\end{array}$ & $\begin{array}{l}\text { XRD, SEM-EDS, } \\
\text { Raman }\end{array}$ \\
\hline
\end{tabular}

XRD and SEM results of basal sediments (or loam, depth from 2.75) revealed the following mineral composition: quartz $(41.2 \%)$, K-feldspar $(4.5 \%)$, plagioclase $(11.6 \%)$, calcite $(10 \%)$, smectite $(7.5 \%)$, chlorite $(9.5 \%)$, illite $(6.5 \%)$, kaolinite $(4.8 \%)$, and up to $4.5 \%$ other minerals (amphiboles, halite, cristobalite, magnetite, zircon, ilmenite, galena, sphalerite, barite, etc.). The lower layer of the eutrophic sequence $(2.25-2.75 \mathrm{~m})$ is a transition zone from loam to peat, so-called organic-rich sediments. Sulfides disappear in the depth interval of $2.5-2.75 \mathrm{~m}$ of organic-rich sediment. The main mineral components of this layer are represented by quartz $(44.8 \%)$, feldspars $(17.2 \%)$, calcite $(7.8 \%)$, smectite $(7.0 \%)$, chlorite $(9.2 \%)$, illite $(4.2 \%)$, and kaolinite (5.6\%). Organic-rich sediments at the depth of 2.25-2.5, are enriched by pyrite, relative to underlying layers, and mainly consist of quartz (43.5\%), feldspars (19.2\%), calcite $(10.1 \%)$, smectite $(3.1 \%)$, chlorite $(10.2 \%)$, illite $(5.7 \%)$, and kaolinite $(4.7 \%)$. The inorganic fractions of the upper layers (depth 1.75-2.25 m) of the eutrophic sequence are characterized by calcite depletion and the predominance of illite (or illite-smectite) with approximately the same set of detrital minerals. The sulfide association in these layers is represented by galena, sphalerite, and single grains of pyrite, 
stibnite, and chalcopyrite. The single inclusion of auricupride with the size of $0.8 \mu \mathrm{m}$ was found by SEM at the depth interval of $2.25-2.5 \mathrm{~m}$.

The mesotrophic peat sequence (depth 1-1.75 m) is distinguished by the predominance of carbonates, especially in the central layer (depth 1.25-1.5 m), and also by the barite enrichment in the upper layer (depth 1-1.5 m), practically without clay minerals. There are quartz, feldspars, zircon, and rutile among the detrital minerals. Fe-bearing spheroids (ferruginous (hydro-)oxides) were found in the lower layer (depth 1.5-1.75 m) of the mesotrophic sequence.

Kaolinite and some detrital minerals (quartz, feldspars, zircon, and Cr-mineral) were observed in the oligotrophic peat sequence (depth $0-1 \mathrm{~m}$ ). There was a predominance of ferruginous (hydro-)oxides and, in rare cases, calcite (at the depth interval $0.5-1 \mathrm{~m}$ ), chalcopyrite and galena (at the depth interval $0.25-0.75 \mathrm{~m}$ ), and sphalerite and gypsum (at the depth interval $0.5-0.75 \mathrm{~m}$ ) in this sequence.

\subsection{Sulfide and Sulfate Minerals}

Among sulfides in the peat deposit, there are pyrite, chalcopyrite, galena, sphalerite, and stibnite, which predominate in the eutrophic sequence and basal sediments (Figure 2). Galena and sphalerite have a close association (Figure $3 \mathrm{a}$ ) and prevail at the depth intervals of $1.75-2.25 \mathrm{~m}$ and $2.75-3 \mathrm{~m}$. The maximum of pyritization was observed in the $2.25-2.5 \mathrm{~m}$ layer.

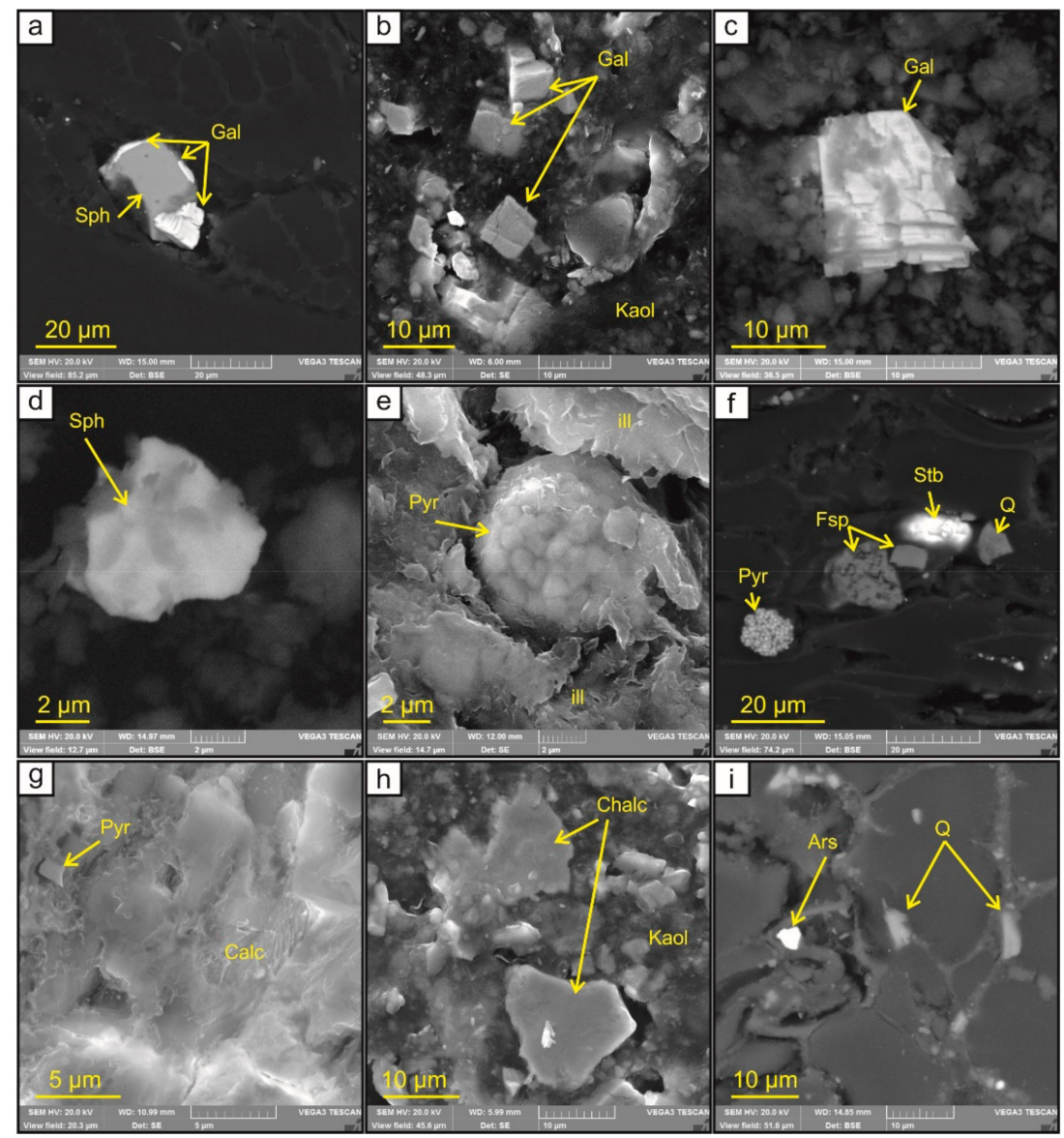

Figure 3. SEM images of sulfides in peat and basal sediments: (a) close association of sphalerite (Sph) and galena (Gal) in Sphagnum tissues; (b) euhedral galena microcrystals in kaolinite aggregate; (c) subhedral galena in smectite matrix; (d) anhedral sphalerite (Sph) crystal in smectite matrix; (e) pyrite (Pyr) framboid in illite (ill) aggregate; (f) pyrite framboid, subhedral stibnite (Stb), and clasts of quartz (Q) and feldspars (Fsp) in Sphagnum tissues; (g) subhedral pyrite crystal in calcite (Calc); (h) anhedral chalcopyrite crystals in kaolinite aggregate; (i) anhedral arsenopyrite and quartz clasts in Sphagnum tissues. The images are $(\mathbf{a}, \mathbf{c}, \mathbf{d}, \mathbf{f}, \mathbf{i})$ backscattered and $(\mathbf{b}, \mathbf{e}, \mathbf{g}, \mathbf{h})$ secondary electron micrographs. 
Galena was observed as euhedral (Figure 3b,c) and subhedral (Figure 3a) microcrystals with sizes from 2 to $24 \mu \mathrm{m}$ in a rare case with sphalerite (Figure 3a). Sphalerite is usually found as anhedral microcrystals (Figure 3d) with sizes of 3-20 $\mu \mathrm{m}$. Galena and sphalerite occur on clay particles (Figure 3b-d) and less often on humic acid aggregates or Sphagnum tissues (Figure 3a,f). Pyrite is characterized by two forms: microframboids (Figure 3e,f) with sizes of $4-8 \mu \mathrm{m}$ and single euhedral and subhedral microcrystals with sizes up to $12 \mu \mathrm{m}$ (Figure 3g). Both pyrite forms are concentrated in clay particles, humic acid aggregates, and Sphagnum tissues, and in a rare case, on calcite (Figure 3g). The impurities of arsenic are fixed with concentrations up to $2.2 \%$ in some pyrite crystals. Chalcopyrite has an anhedral and subhedral grain shape with sizes up to $47 \mu \mathrm{m}$ (Figure $3 \mathrm{~h}$ ) and is usually localized on clay particles. Arsenopyrite and stibnite were found on Sphagnum tissues in single samples as anhedral microcrystals with sizes of 3-4 $\mu \mathrm{m}$ (Figure 3i) and subhedral microcrystals (Figure 3f), respectively.

There were sulfates such as barite, rarely barytocelestine, celestine, and gypsum in the studied section. The maximum distribution of sulfates was observed in the upper layer of the mesotrophic peat sequence (depth 1-1.25 m) and in basal sediments (depth 2.75-3 m).

Barite has an anhedral (Figure 4a) and rare subhedral (Figure $4 \mathrm{~b}$ ) grain shape with a size range from 3.5 to $20 \mu \mathrm{m}$ and is precipitated on clay particles, humic acid aggregates, and Sphagnum tissues. Celestine and gypsum are fixed in rare cases. Celestine was observed in organic-rich sediments (depth 2.25-2.5 m) on smectite particles as anhedral microcrystals (Figure 4c). Gypsum occurs on Sphagnum tissues in association with ferruginous (hydro-)oxides in the oligotrophic sequence.

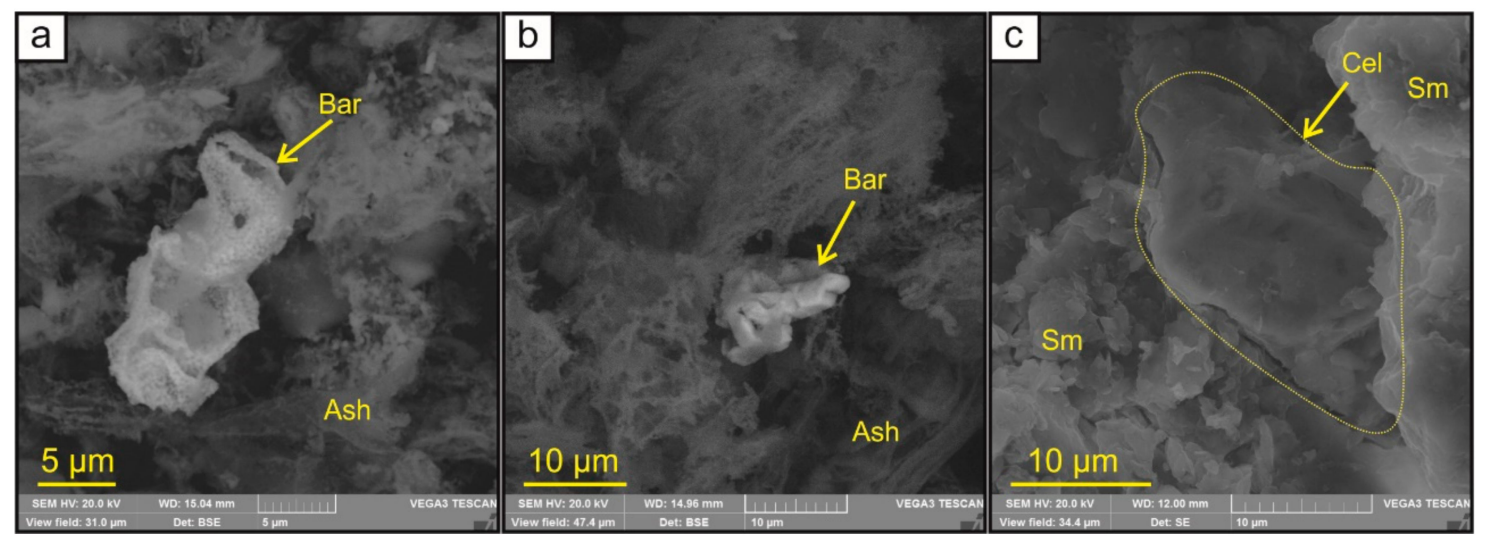

Figure 4. SEM images of Ba- and Sr-sulfate in peat: (a) anhedral barite (Bar) in ash; (b) subhedral barite in ash; (c) anhedral celestine (Cel) in smectite $(\mathrm{Sm})$ matrix. The images are $(\mathbf{a}, \mathbf{b})$ backscattered and (c) secondary electron micrographs.

\subsection{Carbonate and Fe-Bearing (Hydro-)Oxides}

Carbonates in the inorganic component of peat are represented by calcite and dolomite. Calcite prevails with respect to dolomite. The maximum concentration of carbonates (Figure 2) is noted in the mesotrophic peat sequence (especially, at the depth interval 1.25-1.5 m) and in basal sediments as well as in some layers of the eutrophic sequence (1.75-2.25 and 2.5-2.75 m). Dolomite was found in the eutrophic peat sequence (depth interval $2-2.25 \mathrm{~m}$ ) and in basal loam. Calcite is characterized by an anhedral and subhedral grain shape and is concentrated in Sphagnum tissues (Figure 5b). In other cases, calcite forms independent spherical or star-shaped aggregates with sizes up to $50 \mu \mathrm{m}$ (Figure $5 \mathrm{a}$ ). Calcite belongs to the low- $\mathrm{Mg}$ variety and has the following molecular composition: $62.5-100 \% \mathrm{CaCO}_{3}$, $0.5-3.9 \% \mathrm{MgCO}_{3}$, and up to $0.3 \% \mathrm{FeCO}_{3}$. In a rare case, calcite with high $\mathrm{MgCO}_{3}$ content $(11.8 \%)$ was noted. Dolomite rarely occurs in the form of rhombohedral crystals with sizes up to $10 \mu \mathrm{m}$ (Figure $5 \mathrm{c}$ ). Dolomite has the following molecular composition: 37.1-50.0\% $\mathrm{CaCO}_{3}, 26.7-41.9 \% \mathrm{MgCO}_{3}, 0.5-7.7 \%$ $\mathrm{MnCO}_{3}$, and up to $2.1 \% \mathrm{FeCO}_{3}$. 
Fe-bearing (hydro-)oxides predominated in the oligotrophic peat sequence, while they were found much less in the mesotrophic and eutrophic sequences. The maximum of their number occurs at the depth interval of $0.25-1 \mathrm{~m}$. Fe-bearing (hydro-)oxides are characterized by spherical aggregates (Figure $5 \mathrm{~d}$ ) with sizes up to $80 \mu \mathrm{m}$ or individual spheroids (Figure 5e,f) with sizes up to $15 \mu \mathrm{m}$.

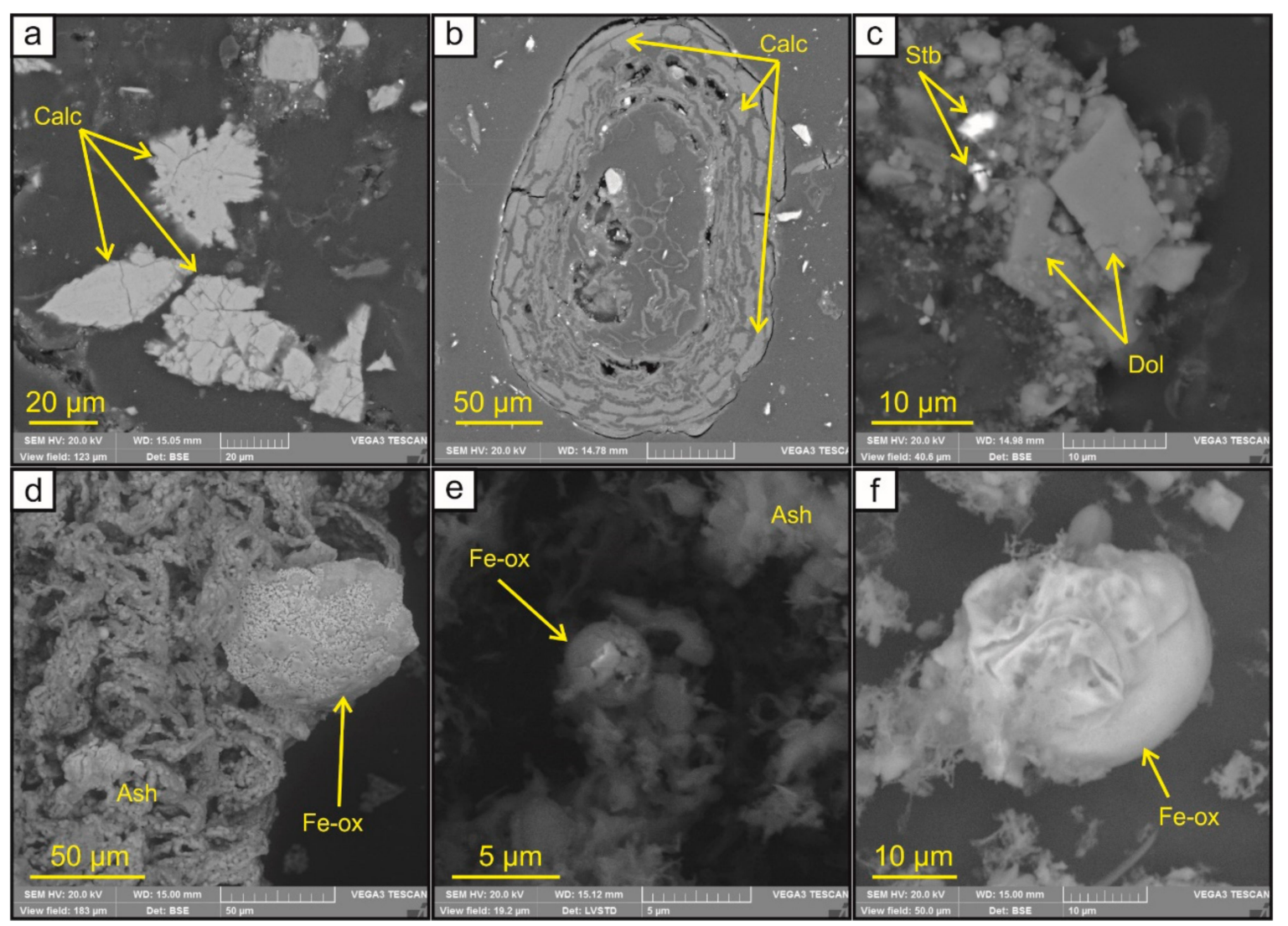

Figure 5. SEM images of carbonate and Fe-bearing (hydro-)oxides in peat: (a) subhedral calcite (Calc) in peat; (b) anhedral calcite in structure of Sphagnum tissues; (c) subhedral dolomite (Dol) and stibnite (Stb) in clay aggregate; (d-f) Fe-bearing (hydro-)oxides (Fe-ox) in ash (within oligotrophic peat sequence). The images are $(\mathbf{a}-\mathbf{d}, \mathbf{f})$ backscattered and (e) secondary electron micrographs.

\section{Discussion}

The sulfides of $\mathrm{Fe}, \mathrm{Pb}, \mathrm{Zn}$, and also $\mathrm{Cu}, \mathrm{Sb}$ and $\mathrm{As}$ were concentrated (Figure 3) mainly in the eutrophic sequence peat and basal loam. A close association of galena and sphalerite (Figure 3a-d) is evidence of joint influx and immobilization of $\mathrm{Pb}$ and $\mathrm{Zn}$ in the peat bog. Atmospheric dust $[8,9,21$, $22,24]$ or groundwater $[4,6]$ are discussed as metal sources in similar environments. The confinement of galena and sphalerite to the eutrophic layers of the peat deposit, the association with carbonates (Figure 2), as well as the absence of the mining industry in the studied area disprove the atmospheric dust source of these metals. The predominance of galena and sphalerite in the basal sediments allows the consideration of two scenarios of the input, mobilization, and precipitation of $\mathrm{Pb}$ and $\mathrm{Zn}$ (as well as $\mathrm{Sb})$. The first scenario is the initial enrichment by trace metals during the formation of loams, then the subsequent diffusion of metals during the clay mineral transformation from smectite to illite, and the immobilization in the sulfides in the zone of bacterial sulfate reduction (BSR). In this case, the contact layer between basal sediments and eutrophic peat represents a transition zone without the precipitation of sulfides. The second scenario is the loading of bog waters by $\mathrm{Pb}$ and $\mathrm{Zn}$ in the initial periods of peat formation (about 2500 years ago [1,8]) with the transport of metal by surface and/or groundwater and subsequent concentration due to the activity of sulfate-reducing microorganisms $[10,14,31,32]$. The contrast predominance of pyrite framboids (Figure 3e,f) below the peat layer with galena and 
sphalerite indicates the advancing pyrite formation in the presence of $\mathrm{Fe}^{2+}$ and $\mathrm{H}_{2} \mathrm{~S}^{-}$ions in the swamp environment.

Barite (Figure $4 a, b)$ is formed at the boundary of geochemical environments, namely: basal sediments vs. eutrophic peat sequence and mesotrophic vs. oligotrophic sequence. These boundaries (or transition zones) correspond to the most contrasting change between the geochemical conditions that are reflected in the distinctive composition of the mineral fraction. Probably, these geochemical condition changes are preceded by the mineralization of the sulfate ions, which remain in the underlying layers. The similar formation conditions of barite with a change of oxic vs. anoxic conditions have been described for the bottom sediments within the Nile deep-sea fan [33] with fixed methane emissions through these sediments. As is known, the origin of barite and celestine in sedimentary sequences could be detrital $[34,35]$, biogenic, and diagenetic for modern and ancient coastal-marine sediments [36-42], hydrothermal [43,44], and cold seeps; then, there is barite formation in conditions of methane seeps [33,45-47]. The association of Ba- and Sr-sulfates with certain layers of the peat deposit indicate against atmospheric dust as the source of these metals. If barium is introduced into a peat deposit from atmospheric dust, a linear trend of barite decreasing or increasing through the peat section should be recorded depending on its solubility [48]. However, the detrital barite has been diagnosed in the peat deposits of the Polish swamps [9,15]. Probably, the Ba and Sr source for the peat deposit is organic matter. The mobilization of these elements occurs under methane emission conditions $[1,49]$ from decomposing abundant organic matter with concentration in the forms of the mineral phases such as barite and celestine (Figure 4) at the boundaries of different geochemical environments (Figure 2).

The occurrence of authigenic mineral phases, which is typical for sedimentary environments, such as calcite, dolomite, pyrite framboids, galena, sphalerite, barite, and ferruginous (hydro-)oxides, excludes the interpretation of their influx into the peat deposit by atmospheric dust. In contrast, the concentration of these minerals is confined to certain geochemical conditions in the peat sequence. Basal sediments with alkaline pore water ( $\mathrm{pH}$ 8.1) are enriched by carbonates, galena, sphalerite, and barite. This mineral assemblage evidence microbial mediation by a consortium of methanogenic and sulfate reducing bacteria. Decreasing filtration properties and oxygen access contribute to the formation of a reducing environment within the basal layer of the peat deposit due to autotrophic sulfate reduction. The oxidation of hydrogen occurs followed by an increase in $\mathrm{pH}$. The eutrophic peat sequence is characterized by changing upwards through a section of associations of authigenic mineral phases (Figure 2): carbonate and Fe-(hydro-)oxide are replaced by pyrite, which goes to galena and sphalerite with a subordinate amount of carbonates and pyrite. This sequence is identical to the methanogenesis zone in the community with bacterial sulfate reduction as a result of the intensive organic matter decomposition. The result of these processes is the newly formed carbonate and sulfide phases [33,50-52]. The mesotrophic sequence with a $\mathrm{pH}$ of $4.6-4.9$ of pore water is enriched by calcite (Figure 5a) with a subordinate amount of ferruginous (hydro-)oxides in the lower layer and a predominance of barite in the upper layer. These facts indicate that the mineral formation processes and the physical-chemical conditions of the pore water are not completely coherent within the peat bog. This is a prospect for future research. The peak of calcite at the depth interval of $1.25-1.5 \mathrm{~m}$ could be interpreted by the anaerobic oxidation of methane (AOM), which influxes from the eutrophic sequence with BSR at the depth interval of 1-1.25 m. The presence of calcite in this layer reflects that physicochemical and biological processes are not necessarily in equilibrium with each other [10]. The depletion of these layers by metals such as $\mathrm{Pb}$ and $\mathrm{Zn}$ led to the concentration of barite (Figure $4 a-c$ ) with the probably biogenic source of barium [33,42,53]. Finally, the oligotrophic sequence is characterized by the development of Fe-bearing (hydro-)oxides (Figure $5 \mathrm{~d}-\mathrm{f}$ ) with a local occurrence of carbonate and sulfides as a result of seasonal fluctuations of the oxidation-reduction conditions.

Given the proposed model, the Vasyugan Swamp should be considered as a dynamically evolving system which concentrates various metals. With the continuation of its evolution, it is possible to predict the further consolidation of the oligotrophic and mesotrophic sequences and their 
transformation to the eutrophic sequence with the pyrite-barite-carbonate association. Thus, the fossil part of the peat deposit with the stability of newly formed mineral phases, that is, the absence of their remobilization, should have a layered distribution of the mineral fraction in its section as described in some lignite deposits [54-56].

\section{Conclusions}

The observed mineral phases within the peat deposit are of detrital, clay, and authigenic origin. The detrital minerals are quartz, feldspars, ilmenite, rutile, magnetite, zircon, monazite, chromite, and amphiboles; clay minerals: illite, kaolinite, smectite, and chlorite; authigenic minerals: carbonates (calcite and dolomite), ferruginous (hydro-)oxides (ferrihydrite and goethite), galena, sphalerite, pyrite, chalcopyrite, barite, celestine, stibnite, cristobalite, halite, rhabdophane, gypsum, baritocelestine, cassiterite, etc.

The formation of $\mathrm{Zn}-, \mathrm{Pb}-$, and $\mathrm{Sb}$-sulfides occurs in anaerobic conditions of eutrophic peat sequences and basal sediments. The pyrite framboid formation is associated with the transition zone between organic-rich sediments and eutrophic peat and is interpreted as the result of active BSR. Above this layer, the specific formation of carbonate phases begins along with clay mineral decrease in parallel with local sulfide formation (galena, sphalerite, chalcopyrite, and stibnite). The peak of specific carbonatization appears in the mesotrophic peat sequence, where probably AOM occurred and it resulted in barite formation as a product of residual BSR in the upper layer. There are kaolinite clay particles with gypsum, galena, chalcopyrite, sphalerite, and relicts of carbonate in the oligotrophic peat sequence. Changes in oxygen concentrations are reflected in newly formed mineral associations in corresponding intervals of the peat. This can be explained by the activity of microbiological processes such as AOM and BSR expressed in specific carbonatization $(100-225 \mathrm{~cm})$ and sulfidization $(175-250 \mathrm{~cm})$, respectively

Given the proposed model, the Vasyugan Swamp should be considered as a dynamically evolving system and it is possible to predict the further consolidation of the oligotrophic and mesotrophic sequences and their transformation to the eutrophic sequence with the pyrite-barite-carbonate association.

Author Contributions: O.S. and A.M. conceived and designed the study; M.R., A.R., A.D., and O.S. performed the laboratory investigations; M.R. and O.S. analyzed the data; M.R., A.R., and O.S. contributed materials; M.R. wrote the paper.

Funding: This research was funded by Russian Foundation for Basic Research (18-05-00302).

Acknowledgments: The field expedition and sample collection were performed with the support by the Russian Government (grant 14.Z50.31.0012). Laboratory investigations were carried out at Tomsk Polytechnic University within the framework of a Tomsk Polytechnic University Competitiveness Enhancement Program grant. The authors thank the editor Jax Jiang and two anonymous reviewers for their detail revisions, which led to improvement of the paper.

Conflicts of Interest: The authors declare no conflict of interest.

\section{Abbreviations}

The following abbreviations are used in this manuscript:

SEM scanning electron microscopy

XRD X-ray diffraction analysis

BSR Bacterial sulfate reduction

AOM anaerobic oxidation of methane

\section{References}

1. Inisheva, L.I.; Kobak, K.I.; Inishev, N.G. Paludification on Vasyugan Mire. Contemp. Probl. Ecol. 2017, 10, 105-110. [CrossRef] 
2. Shvartsev, S.L.; Serebrennikova, O.V.; Zdvizhkov, M.A.; Savichev, O.G.; Naimushina, O.S. Geochemistry of wetland waters from the lower Tom basin, Southern Tomsk oblast. Geochem. Int. 2012, 50, 367-380. [CrossRef]

3. Shotyk, W. Review of the inorganic geochemistry of peats and peatland waters. Earth-Sci. Rev. 1988, 25, 95-176. [CrossRef]

4. Steinmann, P.; Shotyk, W. Geochemistry, mineralogy, and geochemical mass balance on major elements in two peat bog profiles (Jura Mountains, Switzerland). Chem. Geol. 1997, 138, 25-53. [CrossRef]

5. Shotyk, W. Peat bog archives of atmospheric metal deposition: Geochemical evaluation of peat profiles, natural variations in metal concentrations, and metal enrichment factors. Environ. Rev. 1996, 4, 149-183. [CrossRef]

6. Syrovetnik, K.; Puura, E.; Neretnieks, I. Accumulation of heavy metals in Oostriku peat bog, Estonia: Site description, conceptual modelling and geochemical modelling of the source of the metals. Environ. Geol. 2004, 45, 731-740. [CrossRef]

7. López-Buendía, A.M.; Whateley, M.K.G.; Bastida, J.; Urquiola, M.M. Origins of mineral matter in peat marsh and peat bog deposits, Spain. Int. J. Coal Geol. 2007, 71, 246-262. [CrossRef]

8. Veretennikova, E.E. Lead in the natural peat cores of ridge-hollow complex in the taiga zone of West Siberia. Ecol. Eng. 2015, 80, 100-107. [CrossRef]

9. Cabala, J.; Smieja-Król, B.; Jablonska, M.; Chrost, L. Mineral components in a peat deposit: Looking for signs of early mining and smelting activities in Silesia-Cracow region (Southern Poland). Environ. Earth Sci. 2013, 69, 2559-2568. [CrossRef]

10. Awid-Pascual, R.; Kamenetsky, V.S.; Goemann, K.; Allen, N.; Noble, T.L.; Lottermoser, B.G.; Rodemann, T. The evolution of authigenic $\mathrm{Zn}-\mathrm{Pb}-\mathrm{Fe}$-bearing phases in the Grieves Siding peat, western Tasmania. Contrib. Miner. Petrol. 2015, 170, 17. [CrossRef]

11. Eckstein, Y.; Savichev, O.G.; Pasechnik, E.Y. Two decades of trends in ground water chemical composition in The Great Vasyugan Mire, Western Siberia, Russia. Environ. Earth Sci. 2015, 73, 7329-7341. [CrossRef]

12. Shotyk, W.; Bicalho, B.; Cuss, C.W.; Duke, M.J.M.; Noernberg, T.; Pelletier, R.; Steinnes, E.; Zaccone, C. Dust is the dominant source of "heavy metals" to peat moss (Sphagnum fuscum) in the bogs of the Athabasca Bituminous Sands region of northern Alberta. Environ. Int. 2016, 92, 494-506. [CrossRef] [PubMed]

13. Zaccone, C.; Pabst, S.; Senesi, G.S.; Shotyk, W.; Miano, T.M. Comparative evaluation of the mineralogical composition of Sphagnum peat and their corresponding humic acids, and implications for understanding past dust depositions. Quat. Int. 2013, 306, 80-87. [CrossRef]

14. Labrenz, M.; Druschel, G.K.; Thomsen-Ebert, T.; Gilbert, B.; Welch, S.A.; Kemner, K.M.; Logan, G.A.; Summons, R.E.; Stasio, G. De; Bond, P.L.; et al. Formation of sphalerite (ZnS) deposits in natural biofilms of sulfate-reducing bacteria. Science 2000, 290, 1744-1747. [CrossRef] [PubMed]

15. Smieja-Król, B.; Fiałkiewicz-Kozieł, B. Quantitative determination of minerals and anthropogenic particles in some Polish peat occurrences using a novel SEM point-counting method. Environ. Monit. Assess. 2014, 186, 2573-2587. [CrossRef] [PubMed]

16. Postma, D. Formation of siderite and vivianite and the pore-water composition of a Recent bog sediment in Denmark. Chem. Geol. 1980, 31, 225-244. [CrossRef]

17. Peterson, J.C.; Bennett, S.M.; Kramer, L.L. Sulfur mineralization in Sphagnum Peat. Commun. Soil Sci. Plant Anal. 1991, 22, 225-232. [CrossRef]

18. Beltman, B.; Rouwenhorst, T.G.; Van Kerkhoven, M.B.; Van Der Krift, T.; Verhoeven, J.T.A. Internal eutrophication in peat soils through competition between chloride and sulphate with phosphate for binding sites. Biogeochemistry 2000, 50, 183-194. [CrossRef]

19. Kumpiene, J.; Lagerkvist, A.; Maurice, C. Stabilization of $\mathrm{Pb}$ - and $\mathrm{Cu}$-contaminated soil using coal fly ash and peat. Environ. Pollut. 2007, 145, 365-373. [CrossRef] [PubMed]

20. Rothwell, J.J.; Robinson, S.G.; Evans, M.G.; Yang, J.; Allott, T.E.H. Heavy metal release by peat erosion in the Peak District, southern Pennines, UK. Hydrol. Process. 2005, 19, 2973-2989. [CrossRef]

21. Kamenov, G.D.; Brenner, M.; Tucker, J.L. Anthropogenic versus natural control on trace element and $\mathrm{Sr}-\mathrm{Nd}-\mathrm{Pb}$ isotope stratigraphy in peat sediments of southeast Florida (USA), 1500 AD to present. Geochim. Cosmochim. Acta 2009, 73, 3549-3567. [CrossRef] 
22. Kylander, M.E.; Martínez-Cortizas, A.; Bindler, R.; Greenwood, S.L.; Mörth, C.-M.; Rauch, S. Potentials and problems of building detailed dust records using peat archives: An example from Store Mosse (the "Great Bog"), Sweden. Geochim. Cosmochim. Acta 2016, 190, 156-174. [CrossRef]

23. Arbuzov, S.I.; Maslov, S.G.; Finkelman, R.B.; Mezhibor, A.M.; Ilenok, S.S.; Blokhin, M.G.; Peregudina, E.V. Modes of occurrence of rare earth elements in peat from Western Siberia. J. Geochem. Explor. 2018, 184, 40-48. [CrossRef]

24. Shotyk, W.; Weiss, D.; Kramers, J.D.; Frei, R.; Cheburkin, A.K.; Gloor, M.; Reese, S. Geochemistry of the peat bog at Etang de la Gruère, Jura Mountains, Switzerland, and its record of atmospheric $\mathrm{Pb}$ and lithogenic trace metals (Sc, Ti, Y, Zr, and REE) since 12,370 14C yr bp. Geochim. Cosmochim. Acta 2001, 65, 2337-2360. [CrossRef]

25. Mezhibor, A.M.; Arbuzov, S.I.; Arkhipov, V.S. Trace elements in peat bogs of Tomsk Region (South Siberia, Russia). Energy Explor. Exploit. 2013, 31, 629-644. [CrossRef]

26. Mezhibor, A.M.; Arbuzov, S.I.; Rikhvanov, L.P. Accumulation and average contents of trace elements in the high-moor peat of Tomsk Region (Western Siberia, Russia). Energy Explor. Exploit. 2009, 27, 401-410. [CrossRef]

27. Moore, D.M.; Reynolds, R.C., Jr. X-ray Diffraction and the Identification and Analysis of Clay Minerals; Oxford University Press: Oxford, UK, 1997.

28. Hillier, S. Quantitative Analysis of Clay and other Minerals in Sandstones by X-Ray Powder Diffraction (XRPD). In Clay Mineral Cements in Sandstones; Blackwell Publishing Ltd.: Oxford, UK, 2003; pp. $213-251$.

29. Bish, D.L.; Post, J.E. Quantitative mineralogical analysis using the Rietveld full-pattern fitting method. Am. Miner. 1993, 78, 932-940.

30. Taylor, J.C. Computer programs for standardless quantitative analysis of minerals using the full powder diffraction profile. Powder Diffr. 1991, 6, 2-9. [CrossRef]

31. Konhauser, K. Introduction to Geomicrobiology; Wiley-Blackwell: Hoboken, NJ, USA, 2007.

32. Yoon, S.; Yáñez, C.; Bruns, M.A.; Martínez-Villegas, N.; Martínez, C.E. Natural zinc enrichment in peatlands: Biogeochemistry of ZnS formation. Geochim. Cosmochim. Acta 2012, 84, 165-176. [CrossRef]

33. Gontharet, S.; Pierre, C.; Blanc-Valleron, M.-M.; Rouchy, J.M.; Fouquet, Y.; Bayon, G.; Foucher, J.P.; Woodside, J.; Mascle, J. Nature and origin of diagenetic carbonate crusts and concretions from mud volcanoes and pockmarks of the Nile deep-sea fan (eastern Mediterranean Sea). Deep Sea Res. Part II Top. Stud. Oceanogr. 2007, 54, 1292-1311. [CrossRef]

34. Shaw, T.J.; Moore, W.S.; Kloepfer, J.; Sochaski, M.A. The flux of barium to the coastal waters of the southeastern USA: The importance of submarine groundwater discharge. Geochim. Cosmochim. Acta 1998, 62, 3047-3054. [CrossRef]

35. Hanor, J.S.; Chan, L.-H. Non-conservative behavior of barium during mixing of Mississippi River and Gulf of Mexico waters. Earth Planet. Sci. Lett. 1977, 37, 242-250. [CrossRef]

36. Bertram, M.A.; Cowen, J.P. Morphological and compositional evidence for biotic precipitation of marine barite. J. Mar. Res. 1997, 55, 577-593. [CrossRef]

37. Van Beek, P.; Reyss, J.-L.; Bonte, P.; Schmidt, S. Sr/Ba in barite: A proxy of barite preservation in marine sediments? Mar. Geol. 2003, 199, 205-220. [CrossRef]

38. Paytan, A.; Griffith, E.M. Marine barite: Recorder of variations in ocean export productivity. Deep Sea Res. Part II Top. Stud. Oceanogr. 2007, 54, 687-705. [CrossRef]

39. Griffith, E.M.; Paytan, A. Barite in the ocean-Occurrence, geochemistry and palaeoceanographic applications. Sedimentology 2012, 59, 1817-1835. [CrossRef]

40. Fernandes, N.A.; Gleeson, S.A.; Magnall, J.M.; Creaser, R.A.; Martel, E.; Fischer, B.J.; Sharp, R. The origin of Late Devonian (Frasnian) stratiform and stratabound mudstone-hosted barite in the Selwyn Basin, Northwest Territories, Canada. Mar. Pet. Geol. 2017, 85, 1-15. [CrossRef]

41. Núñez-Useche, F.; Canet, C.; Barragán, R.; Alfonso, P. Bioevents and redox conditions around the Cenomanian-Turonian anoxic event in Central Mexico. Palaeogeogr. Palaeoclimatol. Palaeoecol. 2016, 449, 205-226. [CrossRef]

42. Lash, G.G. Authigenic barite nodules and carbonate concretions in the Upper Devonian shale succession of western New York-A record of variable methane flux during burial. Mar. Pet. Geol. 2015, 59, 305-319. [CrossRef] 
43. Terekhov, E.P.; Mozherovsky, A.V.; Barinov, N.N. Barites from the underwater Yamato ridge (Japan Sea) Barites from the underwater Yamato ridge (Japan Sea). Stand. Glob. J. Geol. Explor. Res. 2016, 3, 161-169.

44. Elderfield, H.; Schultz, A. Mid-ocean ridge hydrothermal fluxes and the chemical composition of the ocean. Annu. Rev. Earth Planet. Sci. 1996, 24, 191-224. [CrossRef]

45. Torres, M.E.; Bohrmann, G.; Dubé, T.E.; Poole, F.G. Formation of modern and Paleozoic stratiform barite at cold methane seeps on continental margins. Geology 2003, 31, 897. [CrossRef]

46. Baioumy, H.M. Rare earth elements, $\mathrm{S}$ and $\mathrm{Sr}$ isotopes and origin of barite from Bahariya Oasis, Egypt: Implication for the origin of host iron ores. J. Afr. Earth Sci. 2015, 106, 99-107. [CrossRef]

47. Canet, C.; Anadón, P.; Alfonso, P.; Prol-Ledesma, R.M.; Villanueva-Estrada, R.E.; García-Vallès, M. Gas-seep related carbonate and barite authigenic mineralization in the northern Gulf of California. Mar. Pet. Geol. 2013, 43, 147-165. [CrossRef]

48. Church, T.M.; Wolgemuth, K. Marine barite saturation. Earth Planet. Sci. Lett. 1972, 15, 35-44. [CrossRef]

49. Matthews, E.; Fung, I. Methane emission from natural wetlands: Global distribution, area, and environmental characteristics of sources. Glob. Biogeochem. Cycles 1987, 1, 61-86. [CrossRef]

50. Lin, Z.; Sun, X.; Lu, Y.; Strauss, H.; Xu, L.; Chen, T.; Lu, H.; Peckmann, J. Iron isotope constraints on diagenetic iron cycling in the Taixinan seepage area, South China Sea. J. Asian Earth Sci. 2018, in press. [CrossRef]

51. Jørgensen, B.B.; Kasten, S. Sulfur cycling and methane oxidation. In Marine Geochemistry; Springer-Verlag: Berlin, Germay, 2006; pp. 271-309.

52. Leloup, J.; Loy, A.; Knab, N.J.; Borowski, C.; Wagner, M.; Jørgensen, B.B. Diversity and abundance of sulfate-reducing microorganisms in the sulfate and methane zones of a marine sediment, Black Sea. Environ. Microbiol. 2007, 9, 131-142. [CrossRef] [PubMed]

53. Riedinger, N.; Kasten, S.; Gröger, J.; Franke, C.; Pfeifer, K. Active and buried authigenic barite fronts in sediments from the Eastern Cape Basin. Earth Planet. Sci. Lett. 2006, 241, 876-887. [CrossRef]

54. Ogala, J.; Siavalas, G.; Christanis, K. Coal petrography, mineralogy and geochemistry of lignite samples from the Ogwashi-Asaba Formation, Nigeria. J. Afr. Earth Sci. 2012, 66-67, 35-45. [CrossRef]

55. Foscolos, A.E.; Goodarzi, F.; Koukouzas, C.N.; Hatziyannis, G. Reconnaissance study of mineral matter and trace elements in Greek lignites. Chem. Geol. 1989, 76, 107-130. [CrossRef]

56. Životić, D.; Stojanović, K.; Gržetić, I.; Jovančićević, B.; Cvetković, O.; Šajnović, A.; Simić, V.; Stojaković, R.; Scheeder, G. Petrological and geochemical composition of lignite from the D field, Kolubara basin (Serbia). Int. J. Coal Geol. 2013, 111, 5-22. [CrossRef] 